\title{
KEDUDUKAN HUKUM POSITIF INDONESIA TERHADAP KEBIASAAN MASYARAKAT NELAYAN DALAM KEBIJAKAN BAGI HASIL PERIKANAN DI KECAMATAN MUNCAR KABUPATEN BANYUWANGI
}

\author{
Djoko Wahju Winarno, Rahayu Subekti, Rosita \\ Candrakirana Fakultas Hukum Universitas Sebelas Maret \\ Email : djokowahjuwinarno@gmail.com; rahayusubekti@yahoo.co.id; rositakirana@yahoo.com
}

\begin{abstract}
The Act No. 16 year 1964 on Fisheries harvest-sharing regulated the policy of harvest-sharing on fisheries products in order to improve the welfare of the fishermen. However, the regulation seems to not running well, especially in Muncar District Banyuwangi Regency, where the fishermen were not familiar with the regulation and had their own customs on fisheries harvest-sharing which come across generations. This writing was applying the empirical legal study. The instruments were structured field interview towards fishermen, boat owner, and local government officials, which supported by literature review. Analysis was carried out by interactive model. This study found that the national regulation was unrecognized among the local fishermen and the harvest-sharing policy was based on their local customs. The harvestsharing policy mostly was determined by the boat owner without former agreement. Therefore, the local government should supervise the application of the national regulation on harvest-sharing policy in order to improve the welfare status of the local fishermen. In addition, the ultimate social justice for the community will then be achieved.
\end{abstract}

Keywords: Positive regulation, fishermen, harvest-sharing

\begin{abstract}
Abstrak
Kebijakan pembagian bagi hasil perikanan tangkap diatur oleh hukum positif Indonesia yaitu UU No. 16 Tahun 1964 tentang Bagi Hasil Perikanan. Adanya pengaturan tersebut dimaksudkan untuk meningkatkan kesejahteraan nelayan di Indonesia khususnya di Kecamatan Muncar Kabupaten Banyuwangi. Kenyataannya UU No. 16 Tahun 1964 tersebut tidak dilaksanakan di lingkungan nelayan karena mereka tidak mengetahui adanya aturan tersebut dan mempunyai kebiasaan masyarakat yang sudah turun temurun bagi hasil penangkapan ikan tersendiri. Dalam penulisan ini menggunakan metode penelitian hukum dengan spesifikasi sebagai penelitian hukum empiris. Instrumen pengumpulan data pada penelitian ini adalah wawancara terstruktur yang didukung dengan data kepustakaan, kemudian dilakukan studi atau penelitian lapangan (field research) dalam bentuk wawancara terhadap responden yang terdiri dari juragan pemilik kapal,nelayan, dan aparat pemerintah yang berada di Kabupaten Banyuwangi. Kemudian dilakukan. Analisisis data dilakukan secara kualitatif dengan menggunakan model interaktif. Studi ini menemukan bahwa pembagian hasil perikanan tangkap antara nelayan dengan juragan pemilik kapal mayoritas ditentukan oleh juragan pemilik kapal dan tidak berdasarkan perjanjian tertulis yang disepakati sebelumnya. Peran pemerintah, terutama pemerintah daerah, adalah dengan melakukan pengawasan terhadap pelaksanaan UU No. 16 tahun 1964 tentang Bagi Hasil Perikanan dan membuat aturan pelaksanaan yang disesuaikan dengan daerahnya, khusunya di Kabupaten Banyuwangi. Diharapkan dengan keterlibatan pemerintah daerah dalam pengaturan dan pengawasan bagi hasil perikanan dapat menciptakan keadilan yang substantif sehingga keadilan individu dapat terpenuhi dan keadilan sosial yang bertujuan pada kesejahteraan masyarakat nelayan dapat dicapai.
\end{abstract}

Kata Kunci : Hukum Positif, Nelayan, Bagi Hasil 


\section{A. Pendahuluan}

Salah satu unsur Negara yang penting adalah wilayah. Kekhasan wilayah Indonesia ini dapat dilihat komposisinya yang terdiri dari daratan, perLautan/lautan dan tanah yang ada di bawahnya dan ruang udara di atas Indonesia. Dalam kaitannya dengan wilayah, Indonesia memiliki luas wilayah $5.193 .252 \mathrm{Km}^{2}$ yang terbagi $\mathrm{ke}$ dalam wilayah daratan $1.904 .569 \mathrm{Km}^{2}$ dan wilayah lautan 3.288.683 $\mathrm{Km}^{2}$ serta sekitar 4 juta $\mathrm{Km}^{2}$ merupakan laut Zone Economi Exclusive (Zee), $81.000 \mathrm{Km}$ garis pantai dan di lingkungan pantai inilah sekitar $61 \%$ penduduk Indonesia bertempat tinggal ( Soysa, Chandra H. (editor), 1982 : hal. 115). Menurut S Putu Ardana menyatakan bahwa potensi lestari sumberdaya ikan laut yang dapat ditangkap sekitar 6,2 juta ton pertahun yang terdiri dari potensi perairan Nusantara 4,4 juta ton dan Zee 1,8 juta ton. Potensi sumberdaya ikan laut tersebut baru dimanfaatkan $45 \%$. Potensi kelautan demikian membuka peluang yang sangat besar untuk menciptakan lapangan kerja bagi penduduk, khususnya yang tinggal di daerah pantai untuk melakukan usaha penangkapan ikan. Mereka yang menggantungkan kehidupannya dari pengusahaan ikan ini merupakan nelayan (S Putu Ardana, 2002:hal.24-29). Dalam pengelolaan sumber daya laut dan perikanan ini dibutuhkan peran pemerintah terutama pemerintah daerah yang secara langsung bersinggungan dengan masyarakat nelayan. Sehubungan dengan penyelenggaraan pemerintahan daerah di Indonesia menurut Pasal 18 ayat (1) dan (5) UUD 1945 dibentuk daerah otonom baik itu provinsi, kabupaten atau kota. Daerah ini menyelenggarakan otonomi yang seluas-luasnya, kecuali urusan pemerintahan yang oleh UU tetap dipegang oleh pemerintah pusat. Undang-Undang No.32 Tahun 2004 tentang Pemerintahan Daerah dalam Pasal 18 ayat (1) dan ayat (4) menyatakan bahwa daerah yang memiliki wilayah laut diberikan kewenangan untuk mengelola sumber daya wilayah laut paling jauh 12 mil untuk provinsi dan sepertiganya untuk kabupaten atau kota.

Berkaitan dengan penyelenggaraan otonomi daerah yang memberikan kewenangan daerah untuk mengelola sumber daya wilayah laut maka begitu juga peran pemerintah kabupaten Banyuwangi yang mempunyai peran dalam pengelolaan potensi laut. Kabupaten adalah daerah otonom yang sebagian wilayahnya berupa laut. Kabupaten Banyuwangi yang merupakan salah satu kabupaten di Jawa Timur sebagian wilayahnya berbatasan dengan Selat Bali dan Lautan Hindia memiliki garis pantai sepanjang $175,8 \mathrm{Km}$ dan memiliki kewenangan untuk mengelola wilayah laut maksimal sepanjang 4 (empat) mil laut yang memiliki potensi perikanan sangat besar. Potensi yang demikian ini memberi berkah kepada masyarakat yang tinggal di wilayah pesisir untuk mengais rejeki dari sumber daya laut dengan menggantungkan kehidupannya melakukan penangkapan ikan. Oleh karena itu untuk memperoleh kesejahteraan yang merata bagi masyarakat nelayan pasca penangkapan ikan perlu adanya kebijakan bagi hasil yang adil berdasarkan UU No. 16 tahun 1964 tentang Bagi Hasil Perikanan dalam upaya pengentasan kemiskinan nelayan. Sehingga yang menjadi permasalahan menarik untuk dikaji yaitu mengenai kebijakan pengaturan pemerintah dan pemerintah daerah dalam bagi hasil perikanan dan kendudukan hukum positif di Indonesia dalam menyikapi pelaksanaan bagi hasil perikanan yang dilakukan dengan kebiasaan masyarakat nelayan terutama di kecamatan Muncar kabupaten Banyuwangi.

\section{B. Metode Penelitian}

Penelitian ini merupakan penelitian hukum dengan spesifikasi sebagai penelitian hukum empiris. Dalam hal ini, hukum dimaknai sebagai suatu realitas. Spesifikasi penelitian menekankan pada ilmu hukum dan menitikberatkan pada pengumpulan data sekunder yang merupakan bahan-bahan hukum primer, sekunder, dan tersier (Soerjono Soekanto dan Sri Mamudji, 2006: 14-15). Instrumen pengumpulan data pada penelitian ini adalah wawancara terstruktur yang didukung dengan data kepustakaan, kemudian dilakukan studi atau penelitian lapangan (field research). Analisis data dilakukan secara kualitatif dengan menggunakan model interaktif. Proses analisis dalam penelitian kualitatif, kegiatannya pada dasarnya dilakukan secara bersamaan dengan proses pelaksanaan pengumpulan data. Dalam pelaksanaan penelitian kualitatif, ada tiga komponen utama yang saling berkaitan dan berinteraksi, tidak bisa dipisahkan dari kegiatan pengumpulan data. Oleh karena itu sering dinyatakan bahwa proses analisis dilakukan di lapangan bersamaan dengan proses pengumpulan data sebelum peneliti meninggalkan lapangan studinya (H.B. Sutopo, 2002:94).

\section{Hasil Penelitian dan Pembahasan}

1. Kebijakan dari Pemerintah dan Pemerintah daerah Kabupaten Banyuwangi yang Berkaitan dengan Bagi Hasil Perikanan

Pemerintah dalam melakukan perbuatan pemerintah sendiri dapat dibedakan antara 
perbuatan nyata yaitu perbuatan yang dilakukan pemerintah yang tidak dimaksudkan untuk menimbulkan akibat hukum; perbuatan hukum adalah perbuatan yang dimaksudkan untuk menimbulkan akibat hukum. Mengingat fungsi pemerintah menyangkut penyelenggaraan kepentingan umum (publik), maka yang relevan dalam perbuatan hukum ini adalah perbuatan pemerintah yang didasarkan pada hukum publik. Perbuatan ini dapat berupa peraturan perundangundangan dan keputusan (beschikking). Peraturan perundang-undangan ditujukan untuk menyelesaikan hal-hal yang bersifat umum sama, sedangkan keputusan untuk menyelesaikan kasus kongkrit tertentu.

Ada tiga tahapan dalam kebijakan publik yang meliputi formulasi kebijakan, implementasi kebijakan, dan evaluasi kebijakan. Perihal bagaimana proses kebijakan di atas terbentuk tidak terlepas dari struktur pemerintahan yakni negara kesatuan di Indonesia yang menurut Andrews terdapat tiga faktor utama yang memainkan peranan penting terhadapnya yaitu :

a Bersumber pada kuatnya dan perbedaanperbedaan yang mencolok yang menandai negeri ini.

b. Bersumber pada perkembangan sejarah Indonesia sejak masa-masa pra kolonial hingga dewasa ini.

c. Pengaruh ideologi dan berbagai kebijaksanaan pemerintah (Andrews, Colin Mac ,1993:43).

Dengan mengutip Barclay dan Birkland, Muchsin dan Fadillah Putra menyatakan bahwa kebijakan publik sebagai sebuah konsep pengaturan masyarakat yang lebih menekankan proses, nampaknya kini lebih menjadi lebih populer dari pada hukum. Terkait dengan kebijakan yang dilakukan oleh pemerintah ini Muchsan dalam diskusi di Fakultas Hukum UGM Sabtu tanggal 13 Februari 2010 membedakan adanya dua macam kebijakan yaitu :

a Kebijakan absolut yaitu kebijakan yang diambil oleh pemerintah karena tiadanya peraturan (kevakuman) dalam peraturan perundang-undangan atau tindakan yang mengesampingkan peraturan perundang-undangan karena tindakan tersebut akan member manfaat yang lebih besar.

b. Kebijakan relatif yaitu tindakan yang dilakukan oleh pemerintah atas dasar kewenangannya yang bebas (vrije bestur). Jadi dalam kebijakan yang relatif ini terdapat peraturan perundangundangan. (Djoko Wahju Winarno, 2011 :59)

Berkaitan dengan kebijakan relatif yang berupa peraturan perundang-undangan untuk dapat digunakan dalam mengatur masyarakat khususnya adalah masyarakat nelayan. Nelayan merupakan pihak yang berperan penting dalam penangkapan ikan di perairan laut, hal ini dikarenakan nelayan merupakan buruh yang dipekerjakan oleh juragan pemilik kapal pemilik kapal untuk menangkap ikan di laut. Fakta di lapangan yang terjadi ialah buruh nelayan tereksploitasi oleh juragan pemilik kapal pemilik kapal, yaitu dalam hal pembagian hasil perikanan tangkap antara nelayan dengan juragan pemilik kapal.

Pembagian hasil perikanan tangkap antara nelayan dengan juragan pemilik kapal pemilik kapal mayoritas ditentukan oleh juragan pemilik kapal dan pembagian ini tidaklah berdasar perjanjian yang tertulis berdasarkan kesepakatan diawal antara buruh nelayan dengan juragan pemilik kapal pemilik kapal, yang mana kesepakatan ini dibarengi dengan pemberian pinjaman hutang kepada nelayan, agar buruh nelayan tidak berpindah ke juragan pemilik kapal lain sampai hutangnya lunas. Hal tersebut dapat dikaji melalui peraturan perundangundangan dan kebijakan dari Pemerintah dan Pemerintah Daerah yang berkaitan dengan Bagi Hasil Perikanan,peraturannya sebagai berikut :

1. Kebijakan Pemerintah mengenai Pengaturan Bagi Hasil Perikanan

i. Undang-Undang Dasar RI 1945

- Pasal 33 ayat (3) UndangUndang Dasar Negara Republik Indonesia "Bumi dan air dan kekakayaan alam yang terkandung didalamnya dikuasai oleh negara dan dipergunakan untuk sebesarbesar kemakmuran rakyat"

ii. Konvensi Perserikatan BangsaBangsa mengenai Hukum Laut Tahun 1982

- Indonesia telah meratifikasi konvensi tersebut dengan Undang- Undang Nom or 17 Tahun 1985 t ent ang Pengesahan United Nations 
Convention on the Law of the Sea 1982, menempatkan Indonesia memiliki hak berdaulat (sovereign rights) untuk melakukan pemanfaatan, konservasi, dan pengelolaan sumber daya ikan di Zona ekonomi eksklusif (Zee) Indonesia, dan Laut Lepas yang dilaksanakan berdasarkan persyaratan atau standar internasional yang berlaku.

iii. Undang-Undang Nomor 45 Tahun 2009 tentang Perubahan atas UU No. 31 tahun 2004 tentang Perikanan

a) Pasal 2

Pengelolaan perikanan berdasarkan asas manfaat, keadilan, kemitraan, pemertaan, keterpaduan, keterbukaan, efisiensi, dan kelestarian yang berkelanjutan.

b) Pasal 6 ayat (2)

Pengelolaan perikanan untuk kepentingan penangkapan ikan dan pembudidayaan ikan harus mempertimbangkan hukum adat dan/atau kearifan lokal serta memperhatikan peran serta masyarkat.

c) Pasal 48 ayat (2)

Pungutan perikanan sebagaimana yang dimaksud ayat (1) tidak dikenakan bagi nelayan kecil dan pembudi daya ikan kecil.

d) Pasal 65

Pemerintah dapat memberikan tugas kepada pemerintah daerah untuk melaksanakan urusan tugas pembantuan di bidang perikanan.

iv. Undang-Undang Nomor 16 Tahun 1964 tentang Bagi Hasil Perikanan

a) Pasal 1 huruf a

Perjanjian bagi hasil ialah perjanjian yang diadakan dalam usaha penangkapan at au pemeliharaan ikan antara nelayan pemilik dan nelayan penggarap atau pemilik tambak dan penggarap tambak, menurut perjanjian mana mereka masing-masing menerima bagian dari hasil usaha tersebut menurut imbangan yang telah disetujui sebelumnya.

b) Pasal 1 huruf $g$

Hasil Bersih ialah bagi perikanan laut: hasil ikan yang diperoleh dari penangkapan, yang setelah diambil sebagian untuk "lawuhan" para nelayan penggarap menurut kebiasaan setempat, dikurangi dengan beban-beban yang menjadi tanggungan bersama dari nelayan-nelayan dan para nelayan penggarap, sebagai yang ditetapkan didalam pasal 4 angka 1 huruf a; bagi perikanan darat: sepanjang mengenai ikan pemeliharaan yang diperoleh dari usaha tambak yang bersangkutan dikurangi dengan beban-beban yang menjadi tanggungan bersama dari pemilik tambak dan penggarap tambak, sebagai yang ditetapkan di dalam pasal 4 angka 2 huruf a;

C) Pasal 3 ayat (1) dan (2)

(1) Jika suatu usaha perikanan diselenggarakan atas dasar perjanjian bagi hasil, maka dari hasil usaha itu kepada pihak nelayan penggarap dan penggarap tambak paling sedikit harus diberikan bagian sebagai berikut:

1. perikanan laut:

a jika dipergunakan perahu layar: minimum $75 \%$ (tujuh puluh lima perseratus) dari hasil bersih;

b. jika dipergunakan kapal motor: minimum $40 \%$ (empat puluh perseratus) dari hasil bersih.

(2) Pembagian hasil diantara para nelayan penggarap dari bagian yang mereka terima menurut ketentuan 
dalam ayat (1) pasal ini diatur oleh mereka sendiri, dengan diawasi oleh Pemerintah Daerah Tingkat Il yang bersangkutan untuk menghindarkan terjadinya pemerasan, dengan ketentuan, bahwa perbandingan antara bagian yang terbanyak dan yang paling sedikit tidak boleh lebih dari 3 (tiga) lawan 1 (satu)

d) Pasal 4

Angka bagian pihak nelayan penggarap dan penggarap tambak sebagai yang tercantum dalam pasal 3 ditetapkan dengan ketentuan, bahwa beban-beban yang bersangkutan dengan usaha perikanan itu harus dibagi sebagai berikut:

1. perikanan laut:

a beban-beban yang menjadi tanggungan bersama dari nelayan pemilik dan pihak nelayan penggarap: ongkos lelang, uang rokok/jajan dan biaya perbekalan untuk para nelayan penggarap selama di laut, biaya untuk sedekah laut (selamatan bersama) serta iuran-iuran yang disahkan oleh Pemerintah Daerah $\mathrm{T}$ ingkat II yang bersangkutan seperti unt uk koperasi, dan pembangunan perahu/kapal, dana kesejahteraan, dana kematian dan lainlainnya;

b. beban-beban yang menjadi tanggungan nelayan pemilik: ongkos pemeliharaan dan perbaikan perahu/kapal serta alat-alat lain yang dipergunakan, penyusutan dan biaya eksploitasi usaha penangkapan, seperti untuk pembelian solar, minyak, es dan lain sebagainya.

e) Pasal 7

(1) Perjanjian bagi hasil diadakan untuk waktu paling sedikit 2 (dua) musim, yaitu 1 (satu) tahun berturut-turut bagi perikanan laut dan paling sedikit 6 (enam) musim, yaitu 3 (tiga) tahun berturutturut bagi perikanan darat, dengan ketentuan bahwa jika setelah jangka waktu itu berakhir diadakan pembaharuan perjanjian maka para nelayan penggarap dan penggarap tambak yang lamalah yang diutamakan.

(2) Perjanjian dan bagi hasil tidak terputus karena pemindahan hak atas perahu/kapal, alatalat penangkapan ikan atau tambak yang bersangkutan kepada orang lain. Di dalam hal yang demikian maka semua hak dan kewajiban pemiliknya yang lama beralih kepada pemilik yang baru.

(3) Jika seorang nelayan penggarap atau penggarap tambak meninggal dunia, maka ahli warisnya yang sanggup dan dapat menjadi nelayan penggarap tambak dan menghendakinya, berhak untuk melanjutkan perjanjian bagi hasil yang bersangkutan, dengan hak dan kewajiban yang sama hingga jangka waktunya berakhir.

(4) perjanjian bagi hasil sebelum berakhirnya jangka waktu perjanjian hanya mungkin didalam hal-hal dan menurut ketentuan dibawah ini:

a atas persetujuan kedua belah pihak yang bersangkutan; 
b. dengan izin Panitya

Landreform Desa jika

mengenai perikanan

darat atau suatu

Panitya Desa yang

akan dibentuk jika

mengenai perikanan

laut, atas tuntutan

pemilik, jika nelayan

penggar ap at au

penggarap tambak

yang bersangkutan

tidak memenuhi

ke wa jibanny a

$\mathrm{s}$ e b a g a i m a n a mestinya;

c. jika penggarap tamb ak ta npa persetujuan pemilik tambak menyerahkan pengusaha tambaknya kepada orang lain.

(5) Pada berakhirnya perjanjian bagi hasil baik karena berakhirnya jangka waktu perjanjian maupun karena salah satu sebab tersebut pada ayat (4) pasal ini, nelayan penggarap dan penggarap tambak wajib menyerahkan kembali $\mathrm{kapal} /$ perahu, alat-alat penangkapan ikan dan tambak yang bersangkutan kepada nelayan pemilik dan pemilik tambak dan dalam keadaan baik.

\section{f) Pasal 17}

Pemasaran hasil usaha penangkapan dan pemeliharaan ikan, baik perikanan laut maupun perikanan darat dilakukan menurut cara dan dengan harga yang disetujui bersama oleh nelayan pemilik/pemilik tambak dan nelayan penggarap/ penggarap tambak.

2. Kebijakan Pemerintah Daerah Kabupaten Banyuwangi mengenai Pengaturan Bagi Hasil Perikanan

Pemerintah daerah khususnya Pemerintah Kabupaten Banyuwangi hanyalah sebagai penyedia sarana dan pengawas. Dan dalam hal ini juga pemerintah hanya mampu melihat potensi laut dari segi penerimaan retribusi dan belum memperhatikan segi kesejahteraan buruh nelayan itu sendiri, hal ini dilihat dari regulasi yang dibentuk oleh Pemerintah Kabupaten Banyuwangi, yaitu: Perda Nomor 6 Tahun 2011 tentang Susunan Organisasi Perangkat Daerah, Perda Nomor 13 Tahun 2011 tentang Retribusi Jasa Usaha, Perda Nomor 14 tahun 2011 tentang Retribusi Tertentu, Perbub Nomor 53 Tahun 2011 tentang Susunan, Tata Kerja Dinas Kelautan dan Perikanan.

Sejalan dengan fungsi pemerintah yang berupaya meningkat kan kesejahteraan rakyat maka kebijakan pemerintah baik yang berupa peraturan maupun keputusan, baik yang dikeluarkan oleh pemerintah pusat atau pemerintah daerah esensinya diharapkan menuju terciptanya peningkatan kesejahteraan para nelayan atau sekurang-kurangnya menanggulangi kemiskinan. esmi Warasih memberi penilaian bahwa selama ini hukum di Indonesia (baik berupa peraturan maupun keputusan, penulis) bersifat sentralistik, didominasi oleh lembagalembaga formal seperti eksekutif yang bersifat represif dan dibentuk untuk mempertahankan kekuasaan (status quo), lebih mencerminkan kepentingan kelompok yang memiliki posisi tawar yang kuat, sehingga tidak mencapai tujuan hukum yaitu keadilan (Warasih, esmi, 2001: 23).

Dalam pembuatan kebijakan di bidang perikanan oleh pemerintah dan pemerintah daerah kabupaten Banyuwangi ini merupakan wujud campur tangan pemerintah terhadap aktivitas yang dilakukan oleh nelayan buruh dan juragan pemilik kapal. Meskipun pemerintah kabupaten Banyuwangi tidak mengatur secara khusus bagi hasil perikanan yang dilakukan oleh nelayan dan juragan pemilik kapal dan seharusnya lebih kepada pengawasan terhadap pelaksanaan aturan tersebut. Akan tetapi adanya UU Bagi Hasil Perikanan merupakan wujud tujuan dari hukum yaitu untuk menciptakan tatanan masyarakat yang tertib, menciptakan ketertiban dan keseimbangan. Bahkan 
lebih spesifik lagi bahwa hukum mengabdi kepada tujuan negara, yaitu mendatangkan kemakmuran dan kebahagiaan pada masyarakatnya, dan dalam mengabdi kepada tujuan negara tersebut dilakukan dengan cara penyelenggaraan keadilan dan ketertiban (Mertokusumo, Sudikno,1988 : 57-61).

\section{Kedudukan Hukum Positif Indonesia Terhadap Kebiasaan Masyarakat Nelayan dalam Kebijakan Bagi Hasil Perikanan}

Dalam hukum positif di Indonesia pembagian hasil tangkap perikanan antara nelayan dengan juragan pemilik kapal berdasarkan Undang-Undang Nomor 16 Tahun 1964 tentang Bagi Hasil Perikanan diatur mengenai kesepakatan bersama berdasarkan kapal yang digunakan yaitu perahu layar $75 \%$ sedangkan kapal motor $40 \%$. Meskipun demikian, besaran pembagian hasil tangkapan perikanan ini merupakan batas minimum pembagian hasil perikanan yang sesuai dengan apa yang tertulis pada Pasal 3 ayat (2) yang diperbolehkan untuk mengatur sendiri pembagian hasil tangkapan antara nelayan dengan juragan pemilik kapal pemilik kapal dengan ketentuan diawasi oleh pemerintah kabupaten setempat dan pembagian bagi hasil paling sedikit tidak boleh lebih dari 3 (tiga) lawan 1 (satu) . Untuk pembagian hasil tangkap perikanan antara nelayan dengan juragan pemilik kapal apabila menggunakan perjanjian bagi hasil sesuai dengan Pasal 3 ayat (1) angka 1 huruf a dan b yaitu perahu layar $75 \%$ sedangkan kapal motor 40\%. Dalam pembagian hasil perikanan yang sesuai dengan UndangUndang Nomor 16 Tahun 1964 tentang Bagi Hasil Perikanan tidak hanya diatur mengenai prosentase minimal pembagian hasil perikanan laut tetapi dalam Pasal 1 huruf g Undang-Undang Nomor 16 Tahun 1964 tentang Bagi Hasil Perikanan bahwa biaya yang menjadi tanggungan bersama adalah biaya perbekalan, retribusi dan sedekah laut. Ini berarti hasil bersih yang dibagikan adalah nilai produksi dikurangi dengan jumlah biaya yang menjadi tanggungan bersama. Secara umum dengan menggunakan sistem bagi hasil Undang-Undang Nomor 16 Tahun 1964 tentang Bagi Hasil Perikanan pendapatan yang diterima oleh pemilik menjadi berkurang. Akan tetapi dengan diatur dalam sebuah peraturan perundang-undangan mengenai bagi hasil perikanan tangkap setidaknya nelayan mempunyai kejelasan dalam memperoleh pendapatan untuk meningkatkan kesejahteraan hidup.

Pengaturan mengenai adanya perjanjian bagi hasil perikanan ini dalam UndangUndang Nomor 16 Tahun 1964 tentang Bagi Hasil Perikanan ternyata tidak ketahui oleh buruh nelayan. Sehingga selama ini perjanjian antara buruh nelayan dan juragan pemilik kapal pemilik kapal hanya sebatas lesan dan tidak ada perjanjian tertulis untuk memberikan kepastian dan perlindungan hukum. Hal inilah yang menjadikan kesenjangan kehidupan antara buruh nelayan dengan juragan pemilik kapal pemilik kapal, karena dengan adanya perjanjian bagi hasil inilah sebenarnya berimplikasi pada meningkatnya penghasilan buruh nelayan. Selain itu, nelayan sebagai pemegang garis depan penangkap ikan di laut seharusnya berhak mendapatkan tunjangan asuransi apabila terjadi kecelakaan atau musibah di laut.

Perbedaan penggunaan kebijakan bagi hasil perikanan berdasarkan kebiasaan masyarakat Nelayan Kecamatan Muncar Kabupaten Banyuwangi dengan UndangUndang Nomor 16 Tahun 1964 tentang Bagi Hasil Perikanan,sebagai berikut :

Tabel

Perbandingan Kebiasaan Masyarakat Nelayan Muncar dengan Undang-Undang Nomor 16 Tahun 1964 tentang Bagi Hasil Perikanan

\begin{tabular}{|l|l|l|l|}
\hline No & Perihal & H. Kebiasaan & $\begin{array}{c}\text { Undang- } \\
\text { Undang } \\
\text { Nomor 16 } \\
\text { Tahun 1964 } \\
\text { tentang } \\
\text { Bagi Hasil } \\
\text { Perikanan }\end{array}$ \\
\hline 1 & $\begin{array}{l}\text { Kesepa- } \\
\text { katan }\end{array}$ & Konsensual & $\begin{array}{l}\text { Tertulis dan } \\
\text { konsensual }\end{array}$ \\
\hline 2 & $\begin{array}{l}\text { Jangka } \\
\text { waktu }\end{array}$ & $\begin{array}{l}\text { 6 bulan atau } \\
1 / 2 \text { tahun, } \\
\text { ditawarkan lagi } \\
\text { secara konsen- } \\
\text { sual, akan } \\
\text { tetapi ada yang } \\
\text { tidak memakai } \\
\text { jangka waktu }\end{array}$ & 2 kali musim \\
\hline 3 & $\begin{array}{l}\text { Persen- } \\
\text { tase } \\
\text { Bagian }\end{array}$ & $\begin{array}{l}\text { Berdasarkan } \\
\text { kapal yang } \\
\text { digunakan } \\
\text { oleh nelayan } \\
\text { penggarap } \\
\text { untuk } \\
\text { mengambil ikan }\end{array}$ & $\begin{array}{l}\text { - Perahu } \\
\text { layar 25\% } \\
: 75 \%\end{array}$ \\
\hline $\begin{array}{l}\text { Perahu } \\
\text { motor 40\% } \\
: 60 \%\end{array}$ \\
\hline
\end{tabular}




\begin{tabular}{|c|c|c|c|}
\hline No & Perihal & H. Kebiasaan & $\begin{array}{l}\text { Undang- } \\
\text { Undang } \\
\text { Nomor } 16 \\
\text { Tahun } 1964 \\
\text { tentang } \\
\text { Bagi Hasil } \\
\text { Perikanan }\end{array}$ \\
\hline 4 & $\begin{array}{l}\text { Perbe- } \\
\text { kalan }\end{array}$ & $\begin{array}{l}\text { Ditanggung } \\
\text { oleh nelayan } \\
\text { pemilik/juragan } \\
\text { pemilik kapal } \\
\text { akan tetapi } \\
\text { bila hasil } \\
\text { tangkap sedikit } \\
\text { maka nelayan } \\
\text { penggarap } \\
\text { dipotong } \\
\text { pendapatannya }\end{array}$ & $\begin{array}{l}\text { a. Ditanggung } \\
\text { bersama } \\
\text { (nelayan } \\
\text { pemilik/ } \\
\text { juragan } \\
\text { pemilik } \\
\text { kapal dan } \\
\text { nelayan } \\
\text { penggarap) } \\
\text { b. Ditanggung } \\
\text { nelayan } \\
\text { pemilik/ } \\
\text { juragan } \\
\text { pemilik } \\
\text { kapal }\end{array}$ \\
\hline 5 & $\begin{array}{l}\text { Pemutus- } \\
\text { an } \\
\text { Hubung-an } \\
\text { Kerja }\end{array}$ & $\begin{array}{l}\text { Tidak ada } \\
\text { prosedur } \\
\text { pemutusan } \\
\text { hubungan kerja } \\
\text { akan tetapi } \\
\text { nelayan tdk } \\
\text { boleh berpindah } \\
\text { juragan } \\
\text { pemilik kapal } \\
\text { seenaknya } \\
\text { sediri dengan } \\
\text { sistem mengikat } \\
\text { nelayan } \\
\text { penggarap } \\
\text { dengan hutang }\end{array}$ & $\begin{array}{l}\text { Dengan } \\
\text { berakhirnya } \\
\text { perjanjian } \\
\text { bagi hasil } \\
\text { perikanan }\end{array}$ \\
\hline 6 & $\begin{array}{l}\text { Perlindung- } \\
\text { an nelayan } \\
\text { penggarap }\end{array}$ & $\begin{array}{l}\text { Belum ada } \\
\text { perlindungan } \\
\text { terhadap } \\
\text { nelayan hanya } \\
\text { sekedar cuma- } \\
\text { cuma }\end{array}$ & $\begin{array}{l}\text { Juragan } \\
\text { pemilik } \\
\text { kapal wajib } \\
\text { memberikan } \\
\text { perlindungan } \\
\text { kepada } \\
\text { nelayan } \\
\text { penggarap } \\
\text { berupa } \\
\text { perawatan } \\
\text { dan tunjangan } \\
\text { selama } \\
\text { melakukan } \\
\text { tugas di laut }\end{array}$ \\
\hline 7 & $\begin{array}{l}\text { Pengawas- } \\
\text { an dan } \\
\text { Penyele- } \\
\text { saian } \\
\text { konflik }\end{array}$ & $\begin{array}{l}\text { Belum ada } \\
\text { pengawasan } \\
\text { dalam } \\
\text { pelaksanaan } \\
\text { bagi hasil } \\
\text { dan konflik } \\
\text { diselesaikan } \\
\text { dengan } \\
\text { musyawarah } \\
\text { antara juragan } \\
\text { pemilik kapal } \\
\text { dengan nelayan } \\
\text { penggarap }\end{array}$ & $\begin{array}{l}\text { Diatur } \\
\text { mengenai } \\
\text { pengawasan } \\
\text { dan } \\
\text { perselisihan } \\
\text { diselesaikan } \\
\text { dengan } \\
\text { musyawarah } \\
\text { dengan pihak } \\
\text { ketiga dari } \\
\text { Pemerintah } \\
\text { Daerah }\end{array}$ \\
\hline
\end{tabular}

Sumber: Laporan Penelitian Hibah Bersaing Tahun2013
Dari tabel diatas bahwa dalam hal penentuan kebijakan bagi hasil perikanan diperlukan peran pemerintah dan pemerintah daerah sebagai pemangku kebijakan, untuk mengatur pembagian hasil perikanan berdasarkan hukum positif di Indonesia yaitu Undang-Undang Nomor 16 Tahun 1964 tentang Bagi Hasil Perikanan akan tetapi juga tidak meninggalkan kebiasaan masyarakat khusunya disini masyarakat kecamatan Muncar kabupaten Banyuwangi. Perbandingan penggunaan aturan dalam bagi hasil perikanan dapat dijadikan embrio kebijakan baru yang merupakan terjemahan dari policy dimaknai secara bervariatif. Kebijakan baru tersebut diharapkan mampu memberikan keadilan substantif bagi nelayan buruh. Menurut Bagir Manan, keadilan substantif menyangkut isi keadilan itu sendiri. Untuk dapat menemukan secara tepat substansi keadilan haruslah dibedakan antara keadilan individual (individual justice) dan keadilan sosial (social justice). Sangat ideal apabila keadilan individual tercermin dalam keadilan sosial atau sebaliknya keadilan sosial menjadi tidak lain dari sublimasi keadilan individual. Namun dalam kenyatannya dapat terjadi semacam jarak antara keadilan individual dan keadilan sosial. Jarak ini dapat diatasi atau dikurangi, apabila dalam sistem penegakan hukum dapat dengan cermat diletakan nilai sosial atau moral dari setiap aturan hukum yang akan ditegakkan. Dengan demikian dalam setiap keadilan individual akan terkandung keadilan sosial (Manan, Bagir, 2007: 13). Sehingga penegakan terhadap UU Bagi Hasil Perikanan harus dilakukan oleh pemerintah dan pemerintah daerah agar nelayan buruh yang selama ini dirugikan mendapatkan keadilan secara individual yang nantinya akan menciptakan keadilan sosial yang berupa kesejahteraan para nelayan buruh.

\section{d Simpulan}

Pembagian hasil perikanan tangkap antara nelayan dengan juragan pemilik kapal pemilik kapal mayoritas ditentukan oleh juragan pemilik kapal dan pembagian ini tidaklah berdasar perjanjian yang tertulis berdasarkan kesepakatan diawal antara buruh nelayan dengan juragan pemilik kapal pemilik kapal. Pelaksanaan bagi hasil perikanan yang sudah terjadi antara nelayan dengan juragan pemilik kapal tidak berdasarkan pada hukum positif di Indonesia akan tetapi berdasar pada kebiasaan masyarakat 
yang selama ini telah dilakukan. Hal tersebut terjadi pada masyarkat nelayan yang berada di kecamatan Muncar Kabupaten Banyuwangi. Sehingga peran pemerintah terutama pemerintah daerah dalam melakukan pengawasan terhadap pelaksanaan UU No. 16 tahun 1964 tentang Bagi Hasil Perikanan dan membuat aturan pelaksanaan yang disesuaikan daerahnya terutama Pemerintah Kabupaten Banyuwangi. Diharapkan dengan keterlibatan pemerintah daerah dalam pengaturan dan pengawasan bagi hasil perikanan dapat menciptakan keadilan yang substantif sehingga terpenuhinya keadilan individu untuk mencapai keadilan sosial dengan tujuan akhir kesejahteraan masyarakat nelayan.

\section{E. Saran}

1. Peran pemerintah dalam mengatur dan mengawasi kegiatan yang terjadi antara nelayan dan juragan pemilik kapal. Tidak hanya memandang hasil perikanan tersebut sebagai restribusi saja tetapi memberikan kebijakan yang memberikan keadilan dan kesejahteraan bagi nelayan penggarap.

2. Sosialisi terhadap UU No. 16 Tahun 1964 tentang Bagi Hasil Perikanan agar masyarakat nelayan mengetahui hak dan kewajiban yang harus dilakukan sesuai dengan UU BHP tersebut. Sosialisasi tersebut diharapkan untuk memberikan pengetahuan kepada nelayan dan juragan pemilik kapal,serta menghindari adanya konflik terkait bagihasil perikanan.

3. Diperlukan adanya pemahaman dari nelayan mengenai hak dan wewenang negara untuk melakukan intervensi dalam kehidupan sosial ekonomi masyarkat demi tercapainya kemaslahatan umum. 


\section{daftar Pustaka}

Andrews, Colin Mac. 1993. Struktur Pemerintahan di Indonesia, dalam Hubungan Pusat-Daerah dalam Pembangunan, editor Colin Mac Andrews dan Ichlasul Amal. Jakarta : Rajawali.

Bagir Manan 2007. Sistem Peradilan Berwibawa (Suatu Pencarian). Jakarta : Mahkamah Agung RI.

Chandra H Soysa.(editor). 1982. Man, Land and Sea : Coastal Resources Use and Management in Asia and the Pacific. Bangkok : The Agricultur Development Council.

Djoko Winarno Wahju. 2011. Studi Perbuatan Pemerintah Kabupaten Banyuwangi Dalam Memberikan Perlindungan Hukum Kepada Nelayan. yogyakarta : Program Pascasarjana Ilmu Hukum Fakultas Hukum Universitas Gadjah Mada.

2013. Rekonstruksi Kebijakan Bagi Hasil Perikanan Tangkap Berdasarkan Undangundang Nomor 16 Tahun 1964 Sebagai Upaya Pengentasan Kemiskinan Nelayan di Kabupaten Banyuwangi. Laporan Penelitiah Hibah Bersaing Universitas Sebelas Maret. Surakarta.

esmi Warasih. 2001. Pemberdayaan Masyarakat dalam Mewujudkan Tujuan Hukum (Proses Penegakan Hukum dan Persoalan Peradilan). Pidato Pengukuhan Guru Besar di Fakultas Hukum Undip Semarang.

HB Sutopo. 2002. Metode Penelitian Kualitatif (Dasar-Dasar Teoritis dan Praktis). Surakarta : Pusat Penelitian.

Putu S. Ardana, "Konsepsi Maritim dalam Bingkai Geopolitik Indonesia”. Jurnal Ketahanan Nasional, Nomor VI (3) Desember 2002.

Soerjono Soekanto, Sri Mamudji. 2006. Penelitian Hukum Normatif (Suatu Tinjauan Singkat). Ctk. Pertama. Jakarta : PT. Raja Grafindo Persada.

Sudikno Mertokusumo. 1988. Mengenal Hukum (Suatu Pengantar). yogyakarta : Liberty.

Undang-undang Dasar Republik Indonesia 1945

Undang-undang No. 16 Tahun 1964 tentang Bagi Hasil Perikanan

Undang-undang No.32 Tahun 2004 tentang Pemerintahan Daerah

Undang-Undang Nomor 45 Tahun 2009 tentang Perubahan atas UU No. 31 tahun 2004 tentang Perikanan 